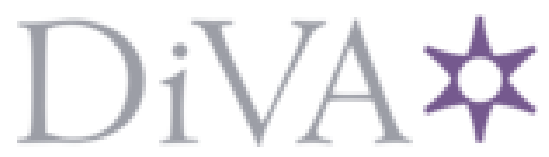

http://www.diva-portal.org

\title{
Postprint
}

This is the accepted version of a paper published in New Journal of European Criminal Law. This paper has been peer-reviewed but does not include the final publisher proof-corrections or journal pagination.

Citation for the original published paper (version of record):

Öberg, J. (2014)

Do we really need criminal sanctions for the enforcement of EU law.

New Journal of European Criminal Law, 5: 370-387

Access to the published version may require subscription.

N.B. When citing this work, cite the original published paper.

Permanent link to this version:

http://urn.kb.se/resolve?urn=urn:nbn:se:oru:diva-3868 1 


\section{DO WE REALLY NEED CRIMINAL SANCTIONS FOR THE ENFORCEMENT OF EU LAW?}

by Jacob Öberg 


\section{TABLE OF CONTENTS}

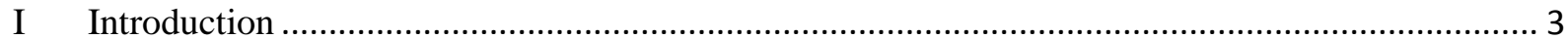

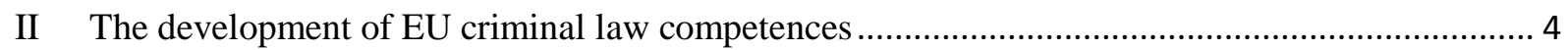

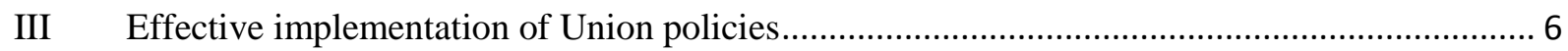

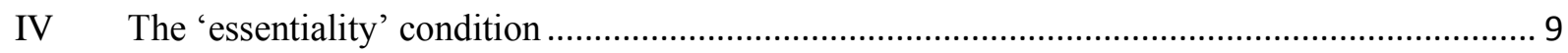

A Linguistic interpretation of the "essentiality condition ............................................................. 9

B The relationship between the 'effectiveness' criterion and the 'essentiality' criterion ............. 10

C What is the evidence needed to demonstrate the 'essentiality' of criminal laws?..................... 12

D How does the proposed interpretation of the 'essentiality' condition fits with the Court's

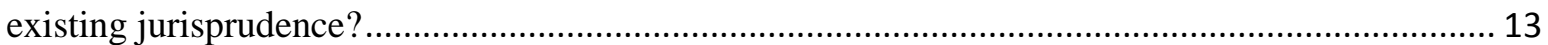

E What is the correct standard of review for assessing whether the 'essentiality' condition is

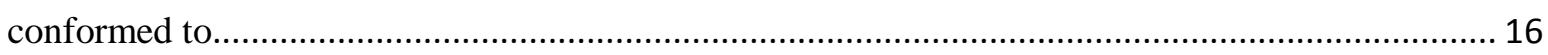

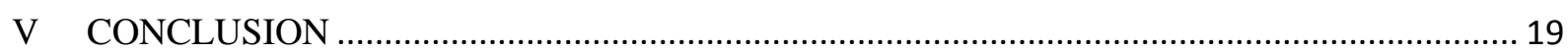


This article examines the role of 'effectiveness' within the scope of Article 83(2) of the Treaty of the Functioning of the European Union (TFEU) ${ }^{1}$. In particular, it tries to respond to the question whether the 'essentiality' criterion in said provision can act as a check on the exercise of EU competences on the basis of the effectiveness rationale. ${ }^{2}$ While Article 83(2) TFEU has been subject to examination by other commentators, the current academic literature has not yet provided substantive criteria for how to interpret this provision. ${ }^{3}$ The key point of this article is that the 'essentiality' criterion provide for one of the most important limits to the competence in Article 83(2) TFEU. In order to articulate the structure of this article, it is appropriate to restate the first part of the wording of Article 83(2) TFEU:

'(I)f the approximation of criminal laws and regulations of the Member States proves essential to ensure the effective implementation of a Union policy in an area which has been subject to harmonisation measures, directives may establish minimum rules with regard to the definition of criminal offences and sanctions in the area concerned..., 4

This article comprehensively analyses the requirement that criminal sanctions shall be 'essential' for the 'effective implementation of Union policies' and also attempts to determine what is meant by 'effective implementation of Union policies'. The first section considers the historical context of Article 83(2) TFEU. This section particularly justifies, in the light of the evolution of EU criminal law, the relevance of examining the conditions for the exercise of EU legislative powers under this provision. The second section asks more specifically, in terms of Article 83(2) TFEU, what effectiveness means for the purposes of EU regulatory criminal law. The third section then considers the meaning of the 'essentiality' requirement. In this regard, a specific focus is put on the issue of the interpretation of the 'essentiality' condition, the question of evidence needed for satisfying this condition and the nature and standard of judicial review under this provision. It is also analysed how the proposed

\footnotetext{
${ }^{1}$ Consolidated Version of the Treaty on the Functioning of the European Union [2010] OJ C 83/47.

${ }^{2}$ See Maria Fletcher, Bill Gilmore and Robin Lööf, EU Criminal Law and Justice (Edward Elgar 2010) 175.

${ }^{3}$ See Steve Peers, EU Justice and Home Affairs Law (OUP 2011) 762-766, 774-777; Paul Craig, The Lisbon Treaty: Law, politics and Treaty reform (OUP 2011) 364-366; Michael Dougan 'From the Velvet Glove to the Iron Fist: Criminal Sanctions for the Enforcement of Union Law' in Marise Cremona (ed), Compliance and the Enforcement of EU Law (OUP 2012) 108-113; Christa Tobler, 'Case C-176/03, Commission v Council' (2006) 43 Common Market Law Review 835, 847-49.

${ }^{4}$ I added emphasis to pinpoint the two conditions which are the subject matter for the present enquiry.
} 
interpretation of the 'essentiality' condition fits with the Court's existing jurisprudence. Finally, the article summarizes the findings of the examination.

Before entering into the analysis of Article 83(2) TFEU it is, appropriate to set out the historical background to the evolution of the EU's criminal law competence and the new provision of Article 83(2) TFEU. If we take a short departure to the history of EU criminal law, it is clear that while the EU today has a far-reaching competence in the field of EU criminal law, this was not always the case. Prior to the Environmental Crimes judgment ${ }^{5}$ and the Lisbon Treaty, the EU only had an indirect and limited influence on national criminal laws. $^{6}$ The rationale for separating criminal law from the realm of EU competences was related to sovereignty and political sensitivity. First, given the differences in legal cultures and the different socio-ethical legal orders in the Member States, it was excessively difficult to find a common European understanding of what behaviours and offences should be subject to criminal sanctions. Secondly, if a power to impose criminal sanction were granted to a supranational organisation, this would possibly compromise the respect for the state as a sovereign entity. ${ }^{7}$

However, as the Community's substantive competences expanded and borders were opened up to ensure the free movement rights, new challenges in combating crime emerged in the form of serious transnational organised crime, such as drug trafficking, money laundering and trafficking in human beings. Such crimes needed enforcement through common action. ${ }^{8}$ Because of these threats to the Community, the Member States decided in the Maastricht Treaty to institute a general cooperation mechanism in EU criminal law by means of the third pillar. While it was recognised that the Union had a competence to combat serious crossborder crimes on an intergovernmental level, a discussion emerged whether such a competence could also be found in the first pillar. The Commission advanced such a criminal

\footnotetext{
${ }^{5}$ See Case C-176/03 Commission v Council (Environmental Crimes) ECR [2005] I-7879.

${ }^{6}$ See Dougan (n3) 76-78; Peers (n3) 777-780; Hanna G Sevenster, 'Criminal Law and EC Law' (1992) 29 Common Market Law Review 29, 39.

${ }^{7}$ See Sandra Lavenex and William Wallace, 'Justice and Home Affairs- Towards a European Public Order' in Helen Wallace, William Wallace and Mark Pollack (eds), Policy-Making in the European Union (OUP 2005); Dougan (n3) 74-75, 91-92.

${ }^{8}$ See David Lowe, 'Justice and Home Affairs and the Third Pillar of Union: EU Criminal Law - In Through the Back Door’ (2006) 2 Journal of Academic Legal Studies 30, 33; Fletcher, Gilmore and Lööf (n2) 23-27.
} 
law competence on the basis that it was needed for the effective enforcement of EU policies. ${ }^{9}$ The Council and the Member States strongly disagreed, arguing that the absence of an express conferral of competence in the Treaties together with concerns for sovereignty militated against recognizing such a competence in the first pillar. ${ }^{10}$

This inter-institutional debate regarding the existence of a first pillar criminal law competence ended up in litigation in the seminal ruling Environmental Crimes. ${ }^{11}$ The Court of Justice of the European Union ('Court') decided, despite strong arguments to the contrary by the Member States, that the Community had a competence under the first pillar to impose criminal law measures on the condition that the conferral of such a competence is 'essential' for the effective implementation of Community environmental policies. ${ }^{12}$ While the reactions to the judgment were critical, ${ }^{13}$ the Court confirmed this ruling two years later in the ShipSource Pollutions judgment. The Court held in the latter judgment that there was a first pillar competence to adopt criminal sanctions also in the field of maritime safety since this was necessary for the enforcement of Community environmental policies. The Court, however, clarified that the Community lacked competence to prescribe the type and level of penalties. ${ }^{14}$

The judgments of the Court clearly undermined the assertion that criminal law belonged to the sovereign sphere of the Member States. The Member State's sovereignty was, nevertheless, even more eroded through the adoption of the new Lisbon Treaty in which an explicit conferral of a Union competence to impose criminal sanctions to enforce substantive Union policies is enshrined in Article 83 (2) TFEU. ${ }^{15}$ Regardless that a competence to enforce substantive Union polices through criminal sanctions has been expressly recognised in Article 83(2) TFEU, the questions on the proper role for criminal sanctions in the enforcement of Union substantive policies remain largely unresolved. ${ }^{16}$ If it was commonly agreed among the Member States that the Union needed the competence in Article 83(1) TFEU to combat

\footnotetext{
${ }^{9}$ See Case C-176/03 Commission v Council (n5), paras 19-21; Case C- 440/05 Commission v Council (ShipSource Pollution) [2007] ECR I-09097, paras 24-25, 28-39. The idea that the effective enforcement of EU law would require criminal sanctions had been proposed earlier by scholars and advocate generals: Case C-240/90 Germany v Commission [1992] ECR I-05383, Opinion of AG Jacobs, para 12; Sevenster (n6) 53-59.

${ }^{10}$ See Martin Wasmeier and Nadine Thwaites, "The "battle of the pillars": does the European Community have the power to approximate national criminal laws?'(2004) 29 European Law Review 613, 616; Case C- 176/03 Commission v Council (n5), paras 26-27.

${ }^{11}$ See Anthony Dawes and Orla Lynskey, 'The ever-longer arm of EC law: the extension of community competence into the field of criminal law’ (2008) 45 Common Market Law Review 131, 132.

${ }^{12}$ See Case C-176/03 Commission v Council (n5), para 48.

${ }^{13}$ See Peers (n2) 772; Valsamis Mitsilegas, EU Criminal Law (Hart 2009) 75-79.

${ }^{14}$ See Case C- 440/05 Commission v Council (n 9), paras 66-70; Dawes and Lynskey (n11) 138-139.

${ }^{15}$ See Craig, The Lisbon Treaty (n3) 364; Ester Herlin-Karnell,' EU Competence in Criminal Law after Lisbon', in Andrea Biondi, Piet Eeckhout and Stefanie Ripley (eds), EU Law After Lisbon (OUP 2012) 333.

${ }^{16}$ See Herlin-Karnell,' EU Competence in Criminal Law after Lisbon' (n 15) 334, 338-339.
} 
particularly serious crime, Article 83(2) TFEU appears to be a more contested provision. This is so for a number of reasons. It is controversial because, firstly, the Union, in contrast to the rulings of the Court which were arguably limited to environmental policy ${ }^{17}$, has been given a general power to impose criminal sanctions in the field of substantive Union policies. ${ }^{18}$ Secondly, since the Union has been given a power to adopt criminal sanctions, which is in sharp contrast to the Court's ruling in the Ship-Source Pollutions judgment ${ }^{19}$; thirdly, given fact that some national courts have expressed their reservation to an excessive use of the Union's new criminal law powers. ${ }^{20}$

This section has shown that the criminal law competence issue has changed in character. Instead of arguing about the conditions for establishing the competence, there is now a fierce debate on when and how this competence can be exercised. ${ }^{21}$ The rest of the article is devoted to examine this question. Having demonstrated the importance of examining how the competence in Article 83(2) TFEU should be exercised, we move on to consider the requirement of 'effective implementation' of EU policies.

Even though Article 83(2) TFEU presume that criminal sanctions contribute to the 'effective implementation' of Union policies, we must press further to understand this concept. A general starting point for the discussion is the general concept of 'effectiveness' in EU law. It has been suggested in the literature that 'effectiveness' implies that law matters, that it has effects on economic, political and social life outside the law. ${ }^{22}$ It therefore includes compliance, enforcement, impact and implementation. In addition to this, we have the concept

\footnotetext{
${ }^{17}$ This was the favoured interpretation by United Kingdom, Ireland and Denmark; see House of Lords' European Union Committee, 42nd Report, Session 2005-06, 'The Criminal Law Competence of the European Community, Report with Evidence, HL Paper 227 19, paras 44-45;See the statements of Judge Puissochet in Sénat, Réunion de la delegation pour l'Union européenne du mercredi 22 février 2006, Institutions européennes, La Cour de justice des Communautés européennes, Audition de M. Philippe Léger, avocat général, et de M. Jean-Pierre Puissochet, juge à la Cour de Justice des Communautés européennes: 'mon sentiment est que l'arrêt est strictement cantonné à la protection de l'environnement et se fonde expressément sur la spécificité de cette matière' < http://www.senat.fr/europe/r22022006_1.html> Accessed 15 May 2014.

${ }^{18}$ See Peers (n3) 774; Craig, The Lisbon Treaty (n3) 365.

${ }^{19}$ Case C-440/05 Commission v Council (n9), para 70; Peers (n3) 764.

${ }^{20}$ See Judgment of German Federal Constitutional Court of 30 June 2009, Lisbon Judgment, Case 2 BvE 2/08, BvE 5/08, 2 BvR 1010/08, BvR 1022/08, BvR 1259/08, BvR182/09 (2009), para 226; Dougan (n2) 112-113.

${ }^{21}$ See Herlin-Karnell,' EU Competence in Criminal Law after Lisbon' (n15) 338-339, 346.

${ }^{22}$ See Francis Snyder 'Effectiveness of European Community Law: Institutions, Processes, Tools and Techniques' (1993) 56 Modern Law Review 19, 19; Phedon Nicolaïdes, 'The Problem of Effective Implementation of EU Rules: an Institutional Solution’ (2001) 36 Interecononomics 14, 16-17.
} 
of 'effective enforcement' which is a well-known concept in EU law which has been used to describe the developments of remedies and other enforcement mechanisms under EU law. ${ }^{23}$ However, since the focus of the analysis in Article 83(2) is not concerned with the 'general effectiveness' of law or 'effective enforcement' but rather the 'effectiveness of criminal law' in relation to the enforcement of EU policies we should dig deeper for a more appropriate concept. $^{24}$

Advocate General Kokott's discussion in the Berlusconi judgment of 'appropriate penalties' is a more precise point of departure for the discussion since she endeavoured to provide some substance in elaborating an understanding of when criminal sanctions are 'effective'. She argued, within the context of ascertaining what the term 'appropriate penalties' means in relation to the publication of false company documents, that rules laying down penalties are 'effective' where they are framed in such a way that they do not make it practically impossible or excessively difficult to impose the penalty provided for and to attain the 'objectives' pursued by Union law. A penalty is further 'dissuasive' where it prevents an individual from infringing the objectives pursued and rules laid down by Union law. ${ }^{25}$

Kokott's reasoning on 'dissuasiveness' is analytically sound since it is based within the framework of the classical law and economics deterrence discourse. The law and economics approach to criminal sanctions is based on the assumption that offenders are rational calculators. If a potential perpetrator is rational, it is envisaged that such an offender will calculate the expected penalty by taking into account the probability of detection, the celerity of the sanction ${ }^{26}$, the probability of successful prosecution, and the severity of the potential sanction. ${ }^{27}$ This logic assumes that crime rates can go down by either increasing severity of sanction, increasing probability of detection or by increasing celerity of the sanction. ${ }^{28}$ If one accepts the rational choice theory, it makes sense to suggest, as Kokott does, that the effectiveness of criminal penalties will, at least partly, depend on the severity of the penalty.

\footnotetext{
${ }^{23}$ See Ester Herlin-Karnell, The Constitutional Dimension of European Criminal Law (Hart 2012) 44-53.

${ }^{24}$ See Case C-440/05 Commission v Council (n9), paras 68-69,

${ }^{25}$ See Joined cases C-387/02, C-391/02 and C-403/02 Berlusconi and Others [2005] ECR I-03565, Opinion of AG Kokott, paras 88-89.

${ }^{26}$ A legal punishment is more costly when it is swifter and the punishment arrives sooner rather than later after the offense; see Raymond Paternoster, 'How Much Do We Really Know about Criminal Deterrence?' (2010) 100 Journal of Criminal Law and Criminology 765,783.

${ }^{27}$ See Gary Becker, 'Crime and Punishment: An Economic Approach' (1968) 76 Journal of Political Economy 169, 207-209; Jeremy Bentham, The Rationale of Punishment (Robert Heward 1830) 19-20.

${ }^{28}$ See Paternoster (n26) 783-784.
} 
Even more pertinent is Kokott's definition of 'appropriate' criminal penalties which envisage that criminal sanctions in order to be 'effective' must be appropriate to achieve a certain Union policy objective of Union law. ${ }^{29}$ Although this is a vague definition, it seems prima facie to be a correct one. First, this definition is consistent with the Commission's official approach to criminal sanctions. The Commission has stated that sanctions can be considered 'effective' when they are capable of ensuring compliance with EU law. ${ }^{30}$ Secondly, this notion of 'effective implementation' is also similar to the concept that emanates from the Court's recent case-law. From the Ship-Source Pollution judgment it can be inferred that 'effectiveness' refers to the capacity of criminal penalties to achieve 'compliance' with Union rules and the extent to which rules are actually complied with in practice. ${ }^{31}$ The definition proposed is thus that criminal law is 'effective' in the 'implementation of Union policies' if they can contribute to achieve the Union objectives in the policy area concerned and contribute to the enforcement of the underlying Union rules. ${ }^{32}$

The first part of the Article 83(2) test is thus that the Union legislator must prove that criminal sanctions do support the realization of the Union objective at issue by specifically achieving higher compliance with the substantive EU rules. If not, the Union cannot exercise its competence under said provision. Having clarified what is meant by 'effective implementation' of Union policies, this contribution turn to consider the 'essentiality' condition.

\footnotetext{
${ }^{29}$ Joined cases C-387/02, C-391/02 and C-403/02 Berlusconi and Others (n25), Opinion of AG Kokott, para 88; Case 326/88 Hansen [1990] ECR I-2911, Opinion of AG Van Gerven, para 8.

${ }^{30}$ See Commission, 'Commission Staff Working Paper, Impact Assessment, Accompanying Document to the Communication from the Commission to the European Parliament, the Council, the European Economic and Social Committee and the Committee of the Regions: Reinforcing sanctioning regimes in the financial services sector', SEC(2010) 1496 final, 11; Commission,' Communication from the Commission to the European Parliament, the Council, the European Economic and Social Committee and the Committee of the Regions: Towards an EU Criminal Policy: Ensuring the effective implementation of EU policies through criminal law', COM (2011) 573 final ('COM 2011/573'), 9.

${ }^{31}$ See Case C-440/05 Commission v Council, (n9) paras 68-69.

${ }^{32}$ See Snyder (n22) 36; COM 2011/573 (n30) 9; Case C-176/03, Commission v Council (n5), Opinion of AG Colomer, para 45; Nicolaïdes (n22) 16-18; Michael G, Faure 'The Implementation of the Environmental Crimes Directives in Europe' (2011) Ninth International Conference on Environmental Compliance and Enforcement 2011, 6. <http://inece.org/conference/9/proceedings/41_Faure.pdf> Accessed 15 May 2014.
} 
This section considers the meaning of the 'essentiality' condition from a linguistic, systematic, contextual and functional perspective. We commence with the linguistic perspective. The ordinary meaning of 'essentiality' in the English language suggests that 'essential' means 'without factor $\mathrm{x}$ result y cannot take place'. It does mean something which in the accomplishment of a given object is indispensable or an absolute necessity. ${ }^{33}$ To take a very simple example, one can imagine a situation where a lower court shall, as a matter of procedure, consider both res judicata (i.e. law $x$ ) and litispendens (law $y$ ) to make a valid decision. ${ }^{34}$ If anyone of these legal principles is disregarded, the judgment is not valid. Consequently, it is 'essential' that both res judicata and litispendens are considered to make a valid decision.

Does the normal linguistic legal usage of 'essentiality' fit with the different language versions of Article 83(2) TFEU ${ }^{35}$ If we first examine the Swedish language version of the Treaty, the expression of 'nödvändig' is used, which translates as 'necessary'. The use of the expression 'absolut nødvendig', which is employed in the Danish language version of the Treaty to describe the Union's competence to resort to criminal sanctions, translates roughly as 'absolutely necessary' in the English language. The Italian language version of the Treaty, which use the term 'indispensabile', corresponds to the French language version of the Treaty, which employs 'indispensable' in relation to the Union's competence to impose criminal sanctions. Both the Italian and the French version of the relevant condition seem to be identical to the English term 'indispensable'. In the Spanish language version of the Treaty the word 'imprescindible', which translates roughly as 'absolutely necessary', is used to describe when the Union can resort to criminal penalties. In the German language version the

\footnotetext{
${ }^{33}$ See Black's Law Dictionary (6th edn, West Publishing co 1990) 546, 1029-1030 for the definition of 'necessary' and 'necessity' which in some contexts have a similar meaning to 'essential'.

${ }^{34}$ See Swedish Code of Judicial Procedure of 1942 (SFS 1942:740), English Translation DS 1998:000, chapter 13, section 6 and chapter 17, section 11.

${ }^{35}$ See Case 283/81 CILFIT v Ministero della Sanità [1982] ECR 3415, paras 18-19.
} 
word 'unerlässlich' is used to illustrate when the EU can use criminal sanctions, which translates as 'indispensable' in the English language.

Even if the linguistic comparison is limited to only seven language versions, it is possible to draw some tentative conclusions, particularly since the language versions of the most influential Member States have been analysed. ${ }^{36}$ All the language versions analysed apart from the Swedish language version, which uses the term 'necessary', suggest that the relevant condition is 'indispensable' or 'absolutely necessary' as these terms are understood in the English language. It follows that 'essential' in the sense of Article 83 (2) TFEU implies semantically that 'without criminal sanctions (X) the effective implementation of Union policy (Y) cannot take place'. ${ }^{37}$ It is only when it is 'absolutely necessary/indispensable' for the effective implementation of a Union policy that the Union should resort to criminal sanctions. ${ }^{38}$ The linguistic interpretation of the 'essentiality' condition thus suggests that the Union legislator will have a substantial burden of substantiating the case for criminal law harmonization under Article 83(2) TFEU.

The relationship between the 'effectiveness' criterion and the 'essentiality' criterion

Having looked at the 'linguistic' meaning of the 'essentiality' condition, the analysis continues with a systematic and principled construction of the 'essentiality' condition. First, we should consider the relationship between the 'effectiveness' criterion discussed above and the 'essentiality' requirement. It transpires that the literature generally has merged these two criteria into the principle of 'effectiveness'. The focus in the literature has been on the principle of 'effectiveness' as a rationale for expansion of EU competences and not on the 'essentiality' condition as a limit to the exercise of EU competences. ${ }^{39}$ Herlin-Karnell has notably claimed that Article 83(2) TFEU provides for an ambiguous and overly broad competence since the all-embracing 'effectiveness' criterion give the Union a carte blanche to legislate under said provision. 'Effectiveness' cannot be a proper constitutional limit to

\footnotetext{
${ }^{36}$ This selection of Member States is based on their absolute population and voting rights in the Council of the European Union. This approach is supported by the Court's case-law; Case 55/87 Moksel v BALM [1988] ECR 3845, para 16; Case C-64/95 Konservenfabrik Lubella v Hauptzollamt Cottbus [1996] ECR I-5105, para 18. The selection of Sweden and Denmark is based on my language skills.

${ }^{37}$ That 'indispensable' has a nearly identical meaning as 'essential' is clear from Black's law Dictionary (n32) $546,773$.

${ }^{38}$ For support of this position: Damian Chalmers, Gareth Davies and Giorgio Monti, European Union Law (2nd edn, CUP 2010) 617; Petter Asp, The Substantive Criminal Law Competence of the EU-Towards an Area of Freedom, Security \& Justice-Part 1 (Jure 2013)130.

${ }^{39}$ See Peers (n3) 762-766, 774-777; Dougan (n3)108-113; Tobler (n3) 847-49.
} 
criminalisation according to her since it has a huge constitutional slipperiness to it. It is far too easy to assume that criminal law is effective in the enforcement of Union law. The 'effectiveness' concept fails to take into account of other enforcement mechanisms under Union law and national law which is regrettable since administrative penalties according to her often are more effective than criminal penalties. ${ }^{40}$

Herlin-Karnell's criticism is justified given the available evidence. Firstly, there is research suggesting that penalties and enforcement activity may have little influence on improving compliance. Criminal law is only effective as a deterrent if it creates internalized social norms which are necessary to foster compliance. ${ }^{41}$ Pinney's and Scholz's empirical research on the US tax system shows that individuals comply with rules not because of a threat of sanctions but instead because of a sense of duty. Individuals adhere to the law for normative reasons, because they perceive that they have a moral obligation to comply. The state's ability to obtain compliance will therefore depend on whether the adopted criminal laws meet the expectations of the citizens of what constitutes condemnable behaviour. ${ }^{42}$ Secondly, criminological research suggests that the threat of criminal sanctions only deters effectively if it correlates with subjective perceptions of risk and threat of punishment. While legislators may modify the objective properties of punishment with the prospect that the subjective perceptions will be affected, there is no necessary correlation between the legally prescribed punishment and subjective perceptions of the risk for punishment. ${ }^{43}$ Thirdly, it is also wellknown in the legal and criminological scholarship that the threat of punishment only works when potential offenders are 'rational' actors. Not all individuals have the capacity to properly identify illegal behaviour, assess risks or make a rational calculation. Some individuals are so optimistic and confident that their ability to assess reality becomes impaired, amounting to a judgment bias. ${ }^{44}$

\footnotetext{
${ }^{40}$ See Herlin-Karnell, The Constitutional Dimension of European Criminal Law (n23) 57-60, 65; HerlinKarnell,' EU Competence in Criminal Law after Lisbon' (n15)' 338-344.

${ }^{41}$ See Geraldine S Moohr, 'An Enron Lesson: The Modest Role of Criminal Law in Preventing Corporate Crime' (2003) 55 Florida Law Review 937, 963, 966, 968, 973; Robert A Kagan and John T Scholz, 'The Criminology of the Corporation and Regulatory Enforcement Strategies' in Keith Hawkins and John M Thomas (eds), Enforcing Regulation (Kluwer-Nijhoff 1984), 71-72; Dan M Kahan, 'Social influence, Social Meaning and Deterrence' (1997) 83 Virginia Law Review 349, 358, 379; Ian Ayres and John Braithwaite, Responsive Regulation: Transcending the Deregulation Debate (OUP 1992) 22-23.

${ }^{42}$ See John T Scholz and Neil Pinney, 'Duty, Fear, and Tax Compliance: The Heuristic Basis of Citizenship Behavior' (1995) 39 American Journal of Political Science 490, 508-509.

${ }^{43}$ See Paternoster (n26) 785-787.

${ }^{44}$ See Moohr (n41) 956, 958, 968; Donald C Langenvoort, 'On Leaving Corporate Executives Naked, Homeless and Without Wheels: Corporate Fraud, Equitable Remedies, and the Debate Over Entity Versus Individual Liability', (2007) 42 Wake Forest Law Review 627, 635. 635; John C Coffee Jr, 'No Soul To Damn - No Body
} 
However, even though it can be questioned whether criminal law is effective in the enforcement of Union law ${ }^{45}$, this criticism does not provide a proper understanding of the constitutional limits of Article 83(2) TFEU. First, we need to distinguish between the 'effectiveness' criterion and the 'essentiality' condition. The 'effectiveness' principle is a different rule than the 'essentiality' condition. Whilst the 'effectiveness' test is a simple one of establishing whether criminal laws in any way contribute positively to the implementation of EU policies, the 'essentiality' test examines whether criminal laws are more effective than non-criminal laws in enforcing the EU policy at issue in terms of dissuasion and achievement of the objectives of the EU policy at issue. I endorse Herlin-Karnell's concern that the 'effectiveness' criterion may not in itself be a restraint to the exercise of EU competences. I, however, argue that the demand to prove that criminal laws are 'essential' for the enforcement of EU policies is a check on EU criminal law harmonization under Article 83(2) TFEU. This is because, the Union must, as argued above ${ }^{46}$, in order to exercise its competence under Article 83(2) TFEU not only prove by empirical evidence that criminal sanctions are 'effective' for the implementation of Union policies but also demonstrate that other sanctions cannot, to an equal extent, achieve 'effective implementation' of a specific Union policy. ${ }^{47}$

\section{What is the evidence needed to demonstrate the 'essentiality' of criminal} laws?

What kind of evidence is then required to support criminalization under Article 83(2) TFEU? Based on the Court's ruling in Spain v Council I argue that there must be 'relevant 'evidence in the legislative background documents such as impact assessments and explanatory memorandums to support the claim for criminalization. The Court must provide with relevant evidence so it can assess whether the EU legislator's discretion was properly exercised. ${ }^{48}$ 'The evidence need to be of such nature that it supports the EU legislator's claim of having exercised its competences consistent with the proposed interpretation of the 'essentiality' condition. If the EU legislator for example would use evidence concerning 'distortions of competition' to justify the 'essentiality' of criminal sanctions it would fail to conform to the standard of taking into account 'relevant' evidence. This is because the 'essentiality' of

\footnotetext{
To Kick - An Unscandalized Inquiry Into the Problem of Corporate Punishment' (1981) 79 Michigan Law Review 386, 400.

${ }^{45}$ See Dougan (n3)101; Valsamis Mitsilegas, 'The Third Wave of Third Pillar Law: Which Direction for EU Criminal Justice?' (2009) 34 European Law Review 523, 533, 536-537.

${ }^{46}$ See above section IV (A).

${ }^{47}$ See Dawes and Lynskey (n11) 144, 149; Asp (n38) 131.

${ }^{48}$ See Case C-310/04 Spain v Council [2006] ECR I-07285, paras 122-123, 133-134.
} 
criminal sanctions can only be justified on the basis of evidence showing that criminal sanctions are more deterrent than other sanctions. ${ }^{49}$ The standard of 'relevant evidence' furthermore entails requirements both in relation to the quantity and quality of the evidence. First, in order to prove for example the deterrent nature of criminal laws, it is necessary to refer to more than one source. If, the evidence for this claim only is sustained with reference to only one study or one scholarly article, this is insufficient. Secondly, the invoked evidence needs to be of a reliable nature which provides serious support for an argument in order to pass the test. Statistical studies, policy studies or scientific articles are examples of such evidence. The evidence for a statement on the effects of criminalization cannot thus be supported by only hearsay evidence but must be supported by either relevant literature or relevant scientific studies. ${ }^{50}$

The demand for 'relevant' evidence cannot, however, be given a too demanding interpretation. If the evidence for a legislative measure is mixed, where some evidence support the 'essentiality' of criminal laws and there is equally strong evidence supporting that non-criminal sanctions are as effective as criminal sanctions, the legality of the measure cannot be contested. One can neither require hard empirical data supporting the assertion that criminal law measures are 'essential' or that criminal sanctions have substantial effects on compliance since such data will seldom be available. Notwithstanding this, the standard of 'relevant' evidence requires a serious attempt to justify the conclusion by means of reference to empirical data in combination with adequate arguments. ${ }^{51}$ This suggest that it is insufficient for the EU legislator to make simple assertions that 'criminal sanctions' are 'effective' and 'essential' in the enforcement of the Union policy at stake. The reasons for criminalization, whether the justifications are sought on the basis of deterrence rationale or on the basis that criminalization improves law enforcement, must be backed up by 'relevant' evidence.

\footnotetext{
${ }^{49}$ See above section IV (A)- (B).

${ }^{50}$ See joined cases C-584/10 P, C-593/10 P and C-595/10 P Commission and others $v$ Kadi, (Court of Justice, 18 July 2013, 'Kadi II') paras 151-162 for the application of the evidence standard. What the Court does is basically to monitor whether any of the relevant reasons submitted, which in theory can support the decision in themselves, is supported by sufficient evidence (para 162). This is, in principle, the same method that I am asking the Court to apply in cases of review of EU legislation adopted under Article 83(2) TFEU.

${ }^{51}$ See Herlin-Karnell, The Constitutional Dimension of European Criminal Law (n23) 59; Asp (n38) 131.
} 
Having defended the importance of the 'essentiality' condition and accounted for the evidence needed to demonstrate compliance with this condition, the examination moves on to consider whether the proposed strict linguistic interpretation of the 'essentiality' requirement fit with the Court's existing jurisprudence. A review of the Court's case-law indicates that the Court's current approach to review of EU legislation is one of restraint. Whilst it is prepared to review whether the Union's legislator has exceeded the limits of its competence, its practice overall demonstrate a deferential review of broad Union measures. ${ }^{52}$ The Court has explicitly conferred a broad discretion to the EU legislative institutions in relation to the legislative choices made in the field of broad Union policies and adopted a 'manifestly inappropriate' test when examining general normative acts' compatibility with the proportionality principle. ${ }^{53}$ Based on the general normative character of criminal law directives and the difficult social-political choices involved, it is arguable that the Court should apply a similar standard for legality under Article 83(2) TFEU as the proportionality test. This test implies that intensity of review would be light and that the lawfulness of a criminal law measure adopted under Article 83(2) TFEU can only be affected if it is 'manifestly inappropriate' in relation to the objective of ensuring 'effective implementation' of a specific EU policy. ${ }^{54}$

The Court's rulings in Environmental Crimes and Ship-Source Pollution should also be taken into account in the analysis given that the principles established by these cases is assumedly guiding for how we shall understand the scope EU's criminal law competence. In this respect, it is argued that the Court's previous approach to judicial review in those cases was even more deferential than its current approach in competence and proportionality litigation. In the Environmental Crimes and the Ship-Source Pollution judgments, the Court merely accepted the Council's assessment that criminal sanctions were 'essential' in those cases for the effective implementation of Union environmental law. ${ }^{55}$ Under the Court's judgments, it seems to be sufficient that the Union institutions consider criminal measures 'essential' for the purposes of the effectiveness of Union law, not that they prove it to be 'essential'. 56

Advocate General Mazák and Dougan have both defended this cautious approach from the Court on the basis of a functional perspective. Advocate General Mazák argued that the

\footnotetext{
${ }^{52}$ See examples of deferential judicial review of EU legislation adopted under Article 114 TFEU: Case C-210/03 Swedish Match [2004] ECR I-11893, paras 36-45; Joined cases C-317/04 and C-318/04 Parliament v Council [2006] ECR I-04721, paras 56, 57, 60, 67-69.

${ }^{53}$ See Paul Craig, EU Administrative Law (OUP 2012) 592-602, with references to the relevant case-law

${ }^{54}$ See Case C-210/03 Swedish Match (n52), para 48.

${ }_{55}^{55}$ See Case C-176/03 Commission v Council (n5), para 50; Case C-440/05 Commission v Council (n9), para 68.

${ }^{56}$ See Tobler (n3) 847-848.
} 
questions of whether criminal measures are in a particular case 'essential' in order to ensure that rules are 'effective' call, not only for objective consideration of the substantive legal basis or policy area in question, but also for a degree of judgment. Bearing this in mind, the Advocate General endorsed the Court's approach as appropriate when the Court established that the Council's view that criminal law was 'essential' for the enforcement of EU environmental policy constituted sufficient evidence to conform to this criterion. ${ }^{57}$ Dougan supports this view and has contended that the issue of whether criminal sanctions are 'essential' is in the first instance a political question not suitable for judicial review. The basic political choice as to the appropriate role and scope of the Union's criminal law powers and its impact on national criminal justice systems should not be open to second-guessing by the Courts. $^{58}$

While Advocate General Mazák's and Dougan's arguments are defendable on functional grounds, their contention does not fit well with the Court's case-law on judicial review of EU legislation in the field of broad EU policies nor is it consistent with the foundations of judicial review. The Court's test in the Environmental Crimes and the Ship Pollution judgments is an even weaker test than the 'manifestly inappropriate' test, which the Court employ when reviewing EU legislation in the field of the common policies. For this reason the Court's approach could be criticised as incoherent. One could reasonably expect the Court to adopt a similar approach in review of EU legislation in the field of criminal law as it has done when reviewing EU legislation in fields of internal market or in other field of the common policies. At least one would not envision the Court to adopt a lighter test than 'manifestly inappropriate' in a field such as criminal law which is sensitive for political reasons and fundamental rights concerns and where such concerns militate against turning the 'essentiality' condition to a political question. ${ }^{59}$ Under the test in the Environmental Crimes judgment the Court would be unable to question the Union legislator's choice even when it appears on the face of it to be patently unreasonable. In the Court's standard case-law on proportionality and the common policies, the Court would at least be able to perform this task. $^{60}$ Secondly, from a more principled perspective it is questionable whether the interpretation favoured by Dougan and Mazák is tenable. Strong scepticism on political and moral grounds should be advanced to the prospect of accepting the Court's de facto slippery

\footnotetext{
${ }^{57}$ See Case C-440/05 Commission v Council (n9), Opinion of AG Mazák, paras 119, 121.

${ }^{58}$ See Dougan (n3) 102.

${ }^{59}$ See Asp (n38) 131.

${ }^{60}$ See Case C-210/03 Swedish Match (n52), para 48.
} 
essentiality test. There is an unacceptable 'moral cost' in allowing a potential legal violation of the 'essentiality' condition to go unsanctioned. ${ }^{61}$ Acceptance of the doctrine would be seriously disturbing since it can cause the Union courts to fall short of upholding the rule of law $^{62}$ and absolve the Court's from its judicial duty to uphold the law pursuant to Article 19 TEU. $^{63}$

Does the analysis so far mean that we should settle for the Court's current application of the 'manifestly inappropriate' standard for review of legislation adopted under Article 83(2) TFEU? I would respond negatively to this question. The problem with the Court's approach to review of EU legislation is not necessarily the standard of review of 'manifestly inappropriate, but the intensity with which this standard is applied. ${ }^{64}$ I sustain that this lowintensity application of the 'manifestly inappropriate' standard is ill-devised to police the exercise of the competence in Article 83(2) TFEU. It is therefore argued that the Court should involve itself in a more intense review of 'essentiality' than what follows from the Court's current approach to review of broad EU legislative measures.

First, even if criminal law is delicate from a policy perspective, this sensitivity does not exclude criminal law from the domain of judicial review. It is rather the case that the nature of criminal law favours a more demanding enquiry of the legality of broad EU criminal law measures. Criminal penalties are liable to severely restrict individual's fundamental right to freedom of movement and property. Imprisonment constitutes counter-breaches of inter alia the liberty and a fine a breach of the right to property of those convicted. Added to this, the imposition of criminal sanctions entails severe stigmatization of the offender. The moral and social blame inherent in every criminal sanction remains firmly attached to the convicted criminal long after the sentence has been served. ${ }^{65}$

\footnotetext{
${ }^{61}$ See Martin H Redish, 'Judicial Review and the "Political Question” ' (1985) 79 Northwestern University Law Review 1031, 1060; Bruce V Harris, 'Judicial Review, Justiciability and the Prerogative of Mercy' (2003) 62 Cambridge Law Journal 631, 633.

${ }^{62}$ See Joined Cases C-402 and 415/05 P Yassin Abdullah Kadi and Al Barakaat International Foundation v Council and Commission [2008] ECR I-6351, Opinion of AG Maduro, paras 34, 45.

${ }^{63}$ See Case C-376/98 Germany v Parliament and Council (Tobacco Advertising) [2000] ECR I-08419, para 84, for the Court of Justices' recognition of its duty under the Treaties to review the exercise of EU competences. ${ }^{64}$ See Craig, EU Administrative Law (n53) 600-601.

${ }^{65}$ See European Convention for the Protection of Human Rights and Fundamental Freedoms, as amended by Protocols Nos. 11 and 14, 4 November 1950, ETS 5, Article 5;Gráinne de Búrca 'The Principle of
} 
Secondly, more serious judicial enquiry of legislation adopted under Article 83(2) TFEU is also justified because of the 'essentiality' requirement's appeal to the principle of ultima ratio. ${ }^{66}$ This principle demands that criminal law is only used in situations of necessity, when something needs to be done because there has been a serious infringement of the interests of society and only when it has been established empirically that other less coercive measures are insufficient. ${ }^{67}$ The Commission itself has also recognized that the ultima ratio principle should be a guiding principle for the EU legislator when it exercises the competence in Article 83(2) TFEU. ${ }^{68}$ If the Court would, as I argue, apply the 'essentiality' condition in the light of the ultima ratio principle, we can expect strict review of EU criminal law legislation and that the Court abandons its current feeble application of the 'manifestly inappropriate' standard for broad EU policies. ${ }^{69}$

Thirdly, from a contextual perspective, a more searching judicial enquiry is furthermore supported by the political statements of the Union institutions which acknowledge the need to take the 'essentiality' requirement seriously. Both the Parliament and the Commission have underlined that the 'essentiality criterion' implicates a need to analyse thoroughly in the impact assessment preceding any legislative proposal whether measures other than criminal law measures could not sufficiently ensure the policy implementation. ${ }^{70}$

Having argued for intense review of the 'essentiality' requirement, it is now appropriate to discuss in more detail the standard for judicial review and test for legality that should be adopted by the Court. Whilst the Court, from a comparative institutional perspective, ${ }^{71}$ may be ill-equipped to reassess factual evidence and the policy choices involved in designing criminal law legislation, there is a solution to the problem of making judicial review of the 'essentiality' condition effective. The suggestion here is that the Court should employ a

\footnotetext{
Proportionality and its Application in EC Law' (1993) 13 Yearbook of European Law 105, 113, 147; Maria Kaiafa-Gbandi, 'The Importance of Core Principles of Substantive Criminal Law for a European Criminal Policy Respecting Fundamental Rights and the Rule of Law' (2011) 1 European Criminal Law Review 7, 17-21; Sakari Melander, 'Ultima Ratio in European Criminal Law' (2013) 3 European Criminal Law Review 45, 52.

${ }^{66}$ That the 'essentiality' condition should be considered in the light of the principle of ultima ratio is clear from a number of important policy documents; COM 2011/573 (n30) 6-8, 12; European Council,' The Stockholm Programme: An Open and Secure Europe Serving and Protecting Citizens', (2010) OJ C 115/1, 4. 5. 2010, C 115/15; CONV 426/02, 'Final report of Working Group X "Freedom, Security and Justice" ‘, Brussels, 2 December 2002, 10.

${ }^{67}$ See Melander (n65) 45-46, 50; Kaiafa Gbandi (n65) 17- 19.

${ }^{68}$ See COM 2011/573 (n30) 7-10.

${ }^{69}$ See Melander (n65) 50-51.

${ }^{70}$ See Parliament,' Report on Legal Bases and Compliance with Community Law', (2001/2151(INI), Final A50180/2003, 22 May 2003, Explanatory Statement, point II, 8-10; COM 2011/573 (n30) 5-7, 11.

${ }^{71}$ See Neil Komesar, 'A Job for the Judges: The Judiciary and the Constitution in a Massive and Complex Society’ (1988) 86 Michigan Law Review 657.
} 
procedural review enquiry to check for compliance under Article 83(2) TFEU. Procedural review of the 'essentiality' condition allows the Court to control compliance with the 'essentiality' condition without intruding upon the Union legislator's margin of appreciation to the appropriateness of a criminal law measure. ${ }^{72}$ Procedural review also facilitates the judicial task since the Court with adequate reasoning and evidence from the EU legislative institutions will be able to properly review whether the 'essentiality' condition has been adhered to. $^{73}$

The suggested standard for legality implies a test of checking firstly whether there is 'adequate' reasoning for the measure's compliance with the 'essentiality' requirement and secondly whether the evidence is 'relevant' to substantiate conformity with said condition. ${ }^{74}$ On the basis of the Court's ruling in Kadi II and Tetra Laval I suggest a test where the EU legislator first must articulate, at least one justification, which in theory is sufficient as basis for sustaining compliance with the 'essentiality' condition exercising the competence. The benchmark to examine whether the justifications are 'adequate' is the relevant criminal law and criminological literature. If the proposed justifications are considered adequate, the second limb of the test considers whether these justifications are supported by 'relevant' evidence. ${ }^{75}$ As suggested above, this evidence needs to be of certain quantity and quality to substantiate the rationale for exercising the competence under Article 83(2) TFEU. ${ }^{76}$ This test for legality provides for more intensity than what follows from the Court's current low-level intensity mode of review which is normally applied in terms of judicial review of broad Union policy measures. The proposed test does, contrary to the Court's approach in Swedish Match $^{77}$, not accept mere reference to preambles as justification for legislation but requires references to evidence in legislative background documents such as impact assessments and explanatory memorandums. The Court must also consider, in contrast to cases such as Vodafone $^{78}$ and Alliance Health ${ }^{79}$, whether the evidence is 'relevant' and fits to the rationale

\footnotetext{
${ }^{72}$ See Stephen Weatherill, 'The limits of legislative harmonisation ten years after Tobacco Advertising: how the Court's case law has become a "drafting guide"” (2011) 12 German Law Journal 827, 846-47; Paul Craig, 'The ECJ and Ultra vires action: a conceptual analysis’ (2011) 48 Common Market Law Review 395, 427.

${ }^{73}$ See Joanne Scott and Susan Sturm,' Court as Catalysts: Re-thinking the Judicial Role in New Governance' (2007) 13 Columbia Journal of European Law 565, 586-91.

${ }^{74}$ See Case C-310/04 Spain v Council (n48) paras 122-123; Scott and Sturm, (n73) 582; Craig, 'The ECJ and Ultra vires action' (n72) 410.

${ }^{75}$ See joined cases C-584/10 P, C-593/10 P and C-595/10 P Commission and others $v$ Kadi (n50), paras 118-119, 124; Case C-12/03 P Commission v Tetra Laval, [2005] ECR I-00987, para 39.

${ }^{76}$ See above section IV (C).

${ }^{77}$ See Case C-210/03 Swedish Match (n52), paras 36-41.

${ }^{78}$ See Case C-58/08 Vodafone and Others, [2010] ECR I-04999, paras 38-47.
} 
for exercising the competence in Article 83(2) TFEU. ${ }^{80}$ The central distinction from the Court's current approach to judicial review of EU legislation is that my proposal asks the Court to be more intrusive when considering whether the necessary facts have been taken into account before exonerating the EU legislator. ${ }^{81}$ It is envisaged that if the EU legislator is not able to provide for, at least, one theoretically compelling justification to defend compliance with the 'essentiality' condition or if the proposed justification is not defended by 'sufficient' and 'relevant' evidence, the Court should invalidate the proposed criminal law measure. ${ }^{82}$

\section{CONCLUSION}

This article set out to consider whether the 'essentiality' condition in Article 83(2) can limit excessive EU harmonization of criminal laws on the basis of the 'effectiveness' rationale.

The article examined two different themes.

The first theme concerned the interpretation of the 'essentiality' condition and the condition of 'effective implementation of EU policies'. I endorsed the law and economics approach to criminal sanctions and suggested that the effectiveness of criminal law is a matter of compliance. I suggested a two part test for demonstrating compliance with the 'essentiality' condition. First, the Union legislator must show by empirical evidence that criminal laws are 'effective' for the implementation of Union policies. Secondly, the EU legislator must demonstrate through such evidence that criminal sanctions are more 'effective' than noncriminal sanctions in the implementation' of a specific Union policy. I also clarified the relationship between distinction between the essentiality condition and the effectiveness

\footnotetext{
${ }^{79}$ See Joined cases C-154/04 and 155/04 Alliance for Natural Health and others [2005] ECR I-06451, paras 3540, $105-107$.

${ }^{80}$ See Alberto Alemanno, 'Regulatory Impact Assessment and European Courts: When Ex Ante Evaluation Meets Ex Post Judicial Control' (2011) 17 European Public Law 485, 501; Xavier Groussout, 'Judgment C310/04, Kingdom of Spain v Council of the European Union' (2007) 44 Common Market Law Review 761, 785; Anne Meuwese, Impact Assessment in EU law-making (2008), 175, 271-272. Doctoral dissertation of 6 February 2008 at the University of Leiden.

<https://openaccess.leidenuniv.nl/bitstream/handle/1887/12589/Thesis.pdf?sequence=3>. Accessed 15 May 2014.

${ }^{81}$ See Weatherill (n72) 859; Andrea Renda Impact Assessments in the EU: The State of the Art And the Art of the State (CEPS 2006) 2; Jeffrey Jovell, 'Administrative Justice and Standards of Substantive Judicial Review' in Anthony Arnull, Piet Eeckhout and P Takis Tridimas (eds), Continuity and Change in EU Law (OUP 2008) 186. ${ }^{82}$ See Case 310/04, Spain v Council (n48), paras 122-135; Scott and Sturm, (n73) 586; Craig, 'The ECJ and Ultra vires action' (n72) 412; Alberto Alemanno, “The Emergence of Evidence-based Judicial Reflex: A Response to Bar-Siman-Tov's Semiprocedural Review' (2013) 1 The Theory and Practice of Legislation 327, 333-335, 338; Ittai Bar-Siman-Tov' Semiprocedural Judicial Review’ (2012) 6 Legisprudence 271, 280, 296.
} 
principle. The 'effectiveness' principle is a different rule than the 'essentiality' condition. Whilst the 'effectiveness' test is a simple one of establishing whether criminal laws in any way contribute positively to the implementation of EU policies, the 'essentiality' test examines whether criminal laws are more effective than non-criminal laws in enforcing the EU policy at issue in terms of dissuasion and achievement of the objectives of the EU policy at issue. Because the 'essentiality' condition not only encompassed a demand to show the effectiveness of criminal laws but a requirement to show criminal laws' prominence over noncriminal sanctions, I maintained that the 'essentiality' condition is a serious check on EU criminal law harmonization under Article 83(2) TFEU.

The second leitmotif of the article was judicial enforcement of the 'essentiality' condition. The enquiry used legal, moral, political and criminological arguments to challenge the rationale of the exercise of EU criminal law competences and to develop a test for judicial review. First, the 'light touch' approach in the Environmental Crimes Case to review of the 'essentiality' condition was rejected as unfounded since it was inconsistent with the Court's previous case-law on review of broad Union policies and because such a standard of review would de facto would bar the Court from reviewing criminal law measures and entail unacceptable moral costs. Secondly, it was argued that the Court's current low intensity application of the 'manifestly inappropriate' standard in the field of broad EU policies was inadequate to ensure proper judicial scrutiny of EU legislation under Article 83(2) TFEU. Given that criminal sanctions are associated with harsh consequences for individuals, given that the 'essentiality' requirement appeals to the ultima ratio principle and given that the Union institutions has officially emphasised that the 'essentiality' criterion must be strictly applied, there was a need for a more comprehensive test than the 'manifestly inappropriate' standard of review.

How then should the Court intensify review of the 'essentiality' condition? There are different options for the Court. The Court could engage in more intense substantive review or develop new heads of review. The reasons based on institutional legitimacy and competence would make it difficult for the Court to move to more fierce substantive review. I sustained that the most appropriate choice of enforcing the 'essentiality' condition is to employ a procedural review enquiry. The main benefit of such review is that since such review only enforces a procedural demand on reasons and evidence, it does not encroach upon the EU legislator's discretion. 
But what test of legality should be chosen to control the legality of EU legislation under Article 83(2) TFEU? A high threshold for legality would give leeway to the EU institutions in its effort to pursue further criminalization on EU level and not stretch the Court's institutional capacities by forcing the Court to become involved in difficult political and constitutional choices. A more demanding test for legality will, however, push the EU legislator to prepare more evidence-based legislation and also increase the legitimacy of the Court and the EU legislative procedure. I considered the latter considerations more important when designing the test. I therefore suggested, on the basis of the Court's ruling in Kadi II and Tetra Laval an intrusive test to control whether the proposed standard of 'adequate reasoning' and 'relevant evidence' has been conformed to. First, the EU legislator must articulate, at least one justification, which in theory, on the basis of the relevant criminal law and criminological literature, is sufficient as basis for defending compliance with the essentiality condition. If the proposed justifications are considered adequate, the second limb of the test considers whether these justifications are supported by 'relevant' and 'sufficient' evidence. This standard demands the evidence to be of a certain quantity and quality. To support for example the deterrent nature of criminal laws or criminal law's stigmatic nature, there need to be references in the legislative background documents to, at least, two different sources. In order to be reliable and adequate, the submitted evidence must be in the form of statistical studies, policy studies and/or scientific articles.

From a broader perspective, this article shows how the nature of the issue shapes judicial review. It was demonstrated that respect for fundamental rights and principles of judicial protection should sharpen judicial review of EU criminal law legislation. It is the fact that the EU potentially has a power to impose imprisonment sanctions in Article 83(2) TFEU which ultimately give a reason for more intense judicial review of the exercise of this power. Because criminal penalties severely restrict individual's fundamental right to freedom of movement and because the imposition of criminal sanctions entails severe stigmatization of the offender, intense judicial review of criminal law measures is justified. 